\title{
The thalassaemia trait in an English family
}

\author{
P. D. ROBERTS
}

From St. Margaret's Hospital, Epping

SYNOPSIS Nine cases of the thalassaemia trait are described in an English family. The problem of distinguishing these cases from those of the common hypochromic anaemias by simple laboratory tests is discussed.

Iron-resistant hypochromic anaemia in people of British ancestry may be caused by the thalassaemia trait. Such cases have been reported by Bywaters (1938), Israëls, Suderman, and Hoogstraten (1955), Israëls and Turner (1955), and Havard, Lehmann, and Bodley Scott (1958). Dacie (1960) mentions similar cases and Callender, Mallet, and Lehmann (1961) recently described the finding of 25 cases in three English families.

\section{METHODS}

Standard haematological techniques were used. $\mathbf{A}_{2}$ haemoglobin was estimated as normal or increased by comparison with normal controls on starch block electrophoresis, and in some cases measured by electrophoresis in Tris buffer on Whatman 100 paper and subsequent elution from the paper. Foetal haemoglobin was measured by the one-minute alkali denaturation method of Singer, Chernoff, and Singer (1951).

\section{CASE REPORT}

The propositus was a woman of 27 , with fair hair and blue eyes, of pure English stock. Hypochromic anaemia had been diagnosed a year previously and despite vigorous treatment with oral and parenteral iron, and various other haematinics, the haemoglobin had remained between 8.5 and $10 \mathrm{~g}$. per $100 \mathrm{ml}$.

On the present admission to the London Hospital the patient had no physical signs other than pallor. Investigation showed a haemoglobin of $9.6 \mathrm{~g}$. per $100 \mathrm{ml}$., packed cell volume (P.C.V.) $34 \%$, M.C.H.C. $28 \%$, white cell count 7,900 per c.mm. with a normal differential count. The blood film showed moderate hypochromasia of the red cells, with some anisocytosis and considerable poikilocytosis. Scanty target red cells were noted and also a few cells with fine basophilic stippling. Marrow aspirated from the sternum showed normoblastic erythropoiesis, with an increase in stainable iron in the normoblasts.

The serum iron was $175 \mu \mathrm{g}$. per $100 \mathrm{ml}$., estimated after a course of intramuscular iron, with a total serum iron-binding capacity of $300 \mu \mathrm{g}$. per $100 \mathrm{ml}$.

There was no evidence of increased intravascular haemolysis: reticulocyte count $2 \%$, serum bilirubin $0.2 \mathrm{mg}$. per $100 \mathrm{ml}$., no increase in urine urobilinogen, direct Coombs test negative, serum haptoglobins normal, and a normal survival curve with ${ }^{51} \mathrm{Cr}$-tagged cells.

Foetal haemoglobin was not increased. Measured by elution from Whatman 100 paper after electrophoresis in Tris buffer, the $A_{2}$ haemoglobin was $7 \%$. No other abnormal haemoglobins were detected.

Further investigations found to be normal included stools for occult blood, plasma proteins and liver function tests, blood urea, urine examination, Heinz body formation with phenyl hydrazine, and a tryptophane-loading test for pyridoxine deficiency.

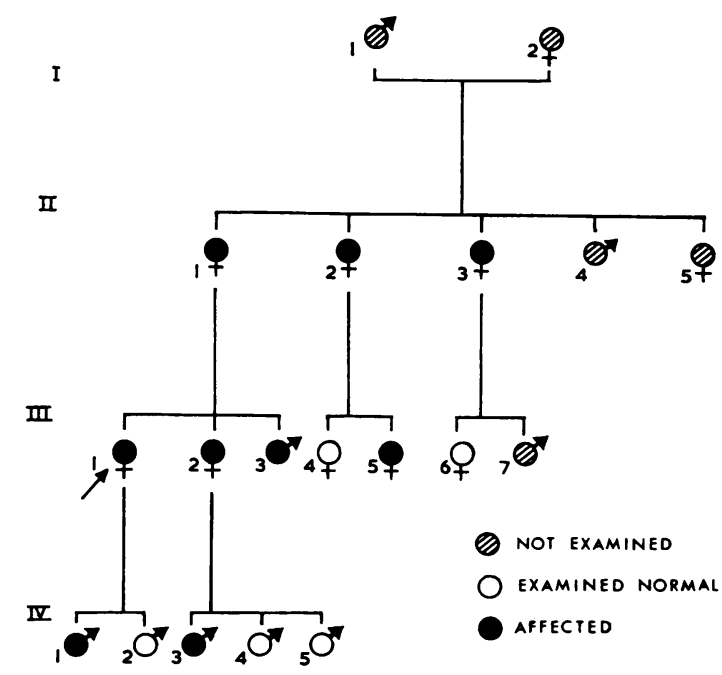

FIG. 1. Pedigree showing cases affected with the thalassaemia trait. 
TABLE I

PERIPHERAL BLOOD FINDINGS IN AFFECTED MEMBERS OF THE FAMILY

\begin{tabular}{|c|c|c|c|c|c|c|c|c|}
\hline \multicolumn{2}{|c|}{$\begin{array}{l}\text { Pedigree } \\
\text { Reference No. }\end{array}$} & $\begin{array}{l}\mathrm{Hb} \\
(\mathrm{g} . / 100 \mathrm{ml} .)\end{array}$ & $\begin{array}{l}\text { M.C.H.C. } \\
(\%)\end{array}$ & $\begin{array}{l}\text { Target } \\
\text { Cells }\end{array}$ & $\begin{array}{l}\text { Stippled } \\
\text { Cells }\end{array}$ & $\begin{array}{l}\mathrm{HbF} F \\
(\%)\end{array}$ & $H b A_{2}$ & $\begin{array}{l}\text { Red Cell } \\
\text { Fragility }\end{array}$ \\
\hline II & 1 & $11 \cdot 7$ & 30 & + & + & 0.9 & + & Decreased \\
\hline II & 2 & $12 \cdot 3$ & 30 & + & + & 0.3 & + & Decreased \\
\hline II & 3 & 11.0 & 28 & + & $\therefore$ & Not done & Not done & Decreased \\
\hline III & 1 & $9 \cdot 6$ & 28 & + & + & Nil & + & Decreased \\
\hline III & 2 & $11 \cdot 2$ & 30 & + & + & 0.7 & + & Decreased \\
\hline III & 3 & $11 \cdot 5$ & 30 & + & + & 0.9 & + & Decreased \\
\hline III & 5 & $12 \cdot 1$ & 29 & + & + & $2 \cdot 4$ & - & Decreased \\
\hline IV & 1 & $9 \cdot 0$ & Not done & + & + & Nil & + & Decreased \\
\hline IV & 3 & $11 \cdot 5$ & 29 & + & + & 0.7 & $T$ & Decreased \\
\hline
\end{tabular}

\section{FAMILY STUDY}

The blood of 13 other members of the family in three generations was examined and eight showed the same condition as the propositus (Fig. 1 and Table I). The haemoglobin level of the affected cases was between $9.0 \mathrm{~g}$. and $12.3 \mathrm{~g}$. per $100 \mathrm{ml}$.

\section{RED CELL OSMOTIC FRAGILITY CHANGES}

The red cells of all the affected cases in this family showed diminished osmotic fragility. In five cases the osmotic fragility was measured after 24 hours' incubation of sterile defibrinated blood with added glucose $(0.05 \mathrm{ml}$. of $10 \%$ glucose per $\mathrm{ml}$. of blood) and without glucose. The changes were compared with 10 normal controls and six cases of iron-deficient hypochromic anaemia (Fig. 2).

The thalassaemia cells became even less fragile after incubation, in contrast to the increase in fragility of normal cells; with added glucose the thalassaemia cells showed a normal increase in fragility. Iron-deficiency hypochromic cells tendect. to behave like the thalassaemia cells but showed $a^{0}$ tail of more fragile cells as well as abnormallyo resistant cells before incubation; incubation pro duced a more marked tail of even more fragile cellso in addition to less fragile cells; incubation with glucose caused a general increase in fragility.

In conjunction with the fragility changes the $\overrightarrow{\vec{r}}$ packed cell volume (P.C.V.) was measured beforeo and after incubation. All the controls showed an increase in P.C.V. of between $4 \%$ and $11 \%$, and between $3 \%$ and $5 \%$ with added glucose. The P.C.V. of cases with the thalassaemia trait decreasede on incubation between $1 \%$ and $3 \%$, this change being reversed to increases of between $4 \%$ and $6 \%$ by adding glucose. Five of the six cases of iron-o deficient hypochromic anaemia showed normal in creases of P.C.V. on incubation, but one behavedo like the cases of thalassaemia. This latter case re $\frac{0}{D}$ ponded completely to iron therapy and on subsequent testing showed the P.C.V. changes of normal blood.⿳⺈

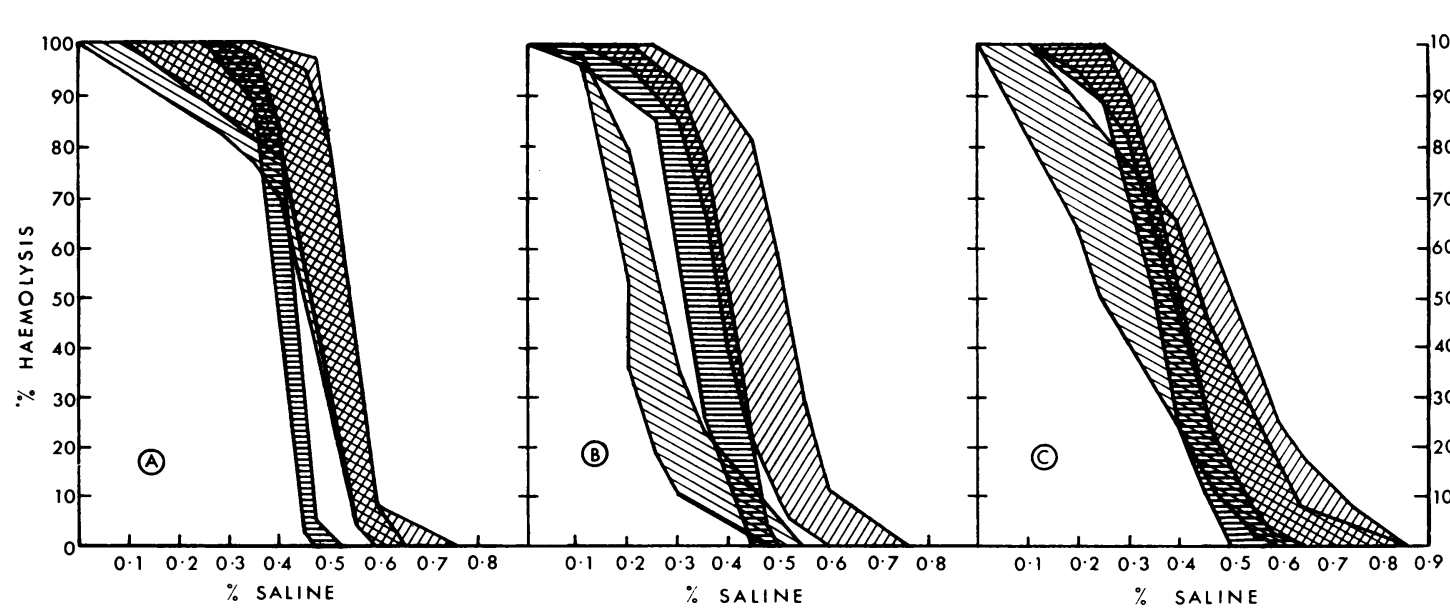

FIG. 2. Red cell osmotic fragility changes in A normal blood (10 cases), $B$ thatassaemia trait (five cases), and $C$ iron-deficient hypochromic anaemia (six cases).

$\equiv$ fresh blood;

incubated blood;

incubated blood with glucose 


\section{DISCUSSION}

There is unfortunately no single feature in the blood film which distinguishes the thalassaemia trait from the common iron-deficient hypochromic anaemia. Contrary to a recent opinion (British Medical Journal, 1961) target cells are commonly seen in iron-deficiency anaemia. In the family described here the number of target cells varied greatly, being strikingly numerous in case II 2 ( $\mathrm{Hb} 12.3 \mathrm{~g}$.) and case III 3 (Hb 11.5 g.) but only scanty in case IV 1 (Hb 9.0 g.) and case III 1 (Hb 9.6 g.). Punctate basophilia is uncommon in iron-deficiency anaemia and its presence should arouse suspicion of thalassaemia: stippled cells may be fairly numerous, as in the propositus of this family, or only found after prolonged search, as in case III 3. As with target cells, the number of stippled cells was not related to the haemoglobin level.

In thalassaemia, despite the hypochromasia, the serum iron level is normal or high and this forms a useful screening test for suspicious cases. The iron state of the patient may be further assessed by demonstrating an excers. of stainable iron in the marrow film in thala. ;mia, as seen in the propositus, in contrast to the absence of such iron in iron-deficiency anaemia.

The red cells in the thalassaemia trait show decreased osmotic fragility and, as described by Selwyn (1953), these cells become even less fragile on incubation, an effect reversed by incubating the blood with glucose. Unfortunately iron-deficiency hypochromic red cells show similar changes although incubation produces a wider scatter of fragility results. Selwyn (1953) also noticed a decrease in the P.C.V. of thalassaemic blood after incubation, and this was seen in the present cases; one case of irondeficiency also showed this change, which reversed to the normal increase after iron therapy. These changes in fragility and P.C.V. are not therefore reliable in distinguishing iron-deficiency anaemia from thalassaemia.

The most important single investigation in such cases of suspected thalassaemia trait is the measurement of the $A_{2}$ haemoglobin fraction. This fraction can be assessed as normal or increased by visual inspection after electrophoresis on starch block, paper, or cellulose acetate. The $\mathrm{A}_{2}$ haemoglobin can be eluted from starch or paper and measured, normal levels being less than about $3 \%$. Of the cases de- scribed by Callender et al. (1961), 24 had raised levels of $\mathrm{A}_{2}$ and one a borderline level: Havard et al. (1958) showed a high $A_{2}$ level in one case. All the affected members of the present family tested for $\mathbf{A}_{2}$ showed a raised level, measured as $7 \%$ in the propositus: one case (II 3) was not tested. Haemoglobin electrophoresis and the demonstration of a raised level of $A_{2}$ haemoglobin distinguishes these cases from those of other refractory anaemias with signs of impaired iron utilization, the haemoglobinopathies, sideroachrestic anaemias, and pyridoxine-responsive anaemia.

Only one of the family described here had a foetal haemoglobin level over $2 \%$ by the one-minute alkali denaturation method (Singer et al., 1951). Four of the cases of Callender et al. (1961) had a level of foetal haemoglobin over $2 \%$, estimated by the same method: an increase was recorded in the cases of Israëls et al. (1955), of Israëls and Turner (1955), and of Havard et al. (1958).

As illustrated here, a family survey will reveal further affected cases. These patients had no obvious ill-effects from the mild anaemia: some who had been diagnosed previously as hypochromic anaemia were relieved to know that they no longer required iron tablets and further blood tests.

The finding of further similar cases since this family was investigated suggests that the thalassaemia trait is a not uncommon cause of ironrefractory hypochromic anaemia in British people.

I am indebted to Dr. D. G. Penington for help in investigating this family. I also thank Dr. J. F. Wilkinson and Dr. M. C. G. Israëls for facilities at Manchester Royal Infirmary, Professor $H$. Harris for the starch block electrophoresis, and Dr. R. R. Bomford for permission to investigate a patient under his care.

\section{REFERENCES}

British Medical Journal (1961). 2, 1139.

Bywaters, E. G. L. (1938). Arch. Dis. Childh., 13, 173.

Callender, S. T., Mallet, B. J., and Lehmann, H. (1961). Brit. J. Haemat., 7, 1.

Dacie, J. V. (1960). The Haemolytic Anaemias, Congenital and Acquired, 2nd ed. Part 1. Churchill, London.

Havard, C. W. H., Lehmann, H., and Bodley Scott, R. (1958). Brit. med. J., 1, 304.

Israëls, L. G., Suderman, H. J., and Hoogstraten, J. (1955). Lancet, $2,1318$.

Israëls, M. C. G., and Turner, R. L. (1955). Ibid., 2, 1363.

Selwyn, J. G. (1953). Unpublished observations, quoted by Dacie, J. V. (1960). in The Haemolytic Anaemias, Congenital and Acquired, 2nd ed. Part 1. Churchill, London.

Singer, K., Chernoff, A. I., and Singer, L. (1951). Blood, 6, 413. 